\title{
PERSEPSI ORANG TUA TERHADAP PROSES BIMBINGAN BELAJAR ANAK DI RUMAH
}

\author{
Suwarto ${ }^{1}$, Hulman Fajri ${ }^{2}$ \\ STMIK Raharja Tangerang Jurusan Sistem Informasi ${ }^{1}$ \\ SMP Negeri 5 Cileles Kabupaten Lebak Propinsi Banten ${ }^{2}$ \\ Email: suwarto@raharja.info ${ }^{1}$
}

\begin{abstract}
Abstrak
Persepsi selalu berkaitan dengan gejala dan pengalaman yang dimiliki.Semakin banyak pengalaman dan ilmu pengetahuan pada diri seorang maka semakin banyak dan kuat persepsinya.Selain ilmu pengetahuan dan pengalaman, persepsi juga dipengaruhi oleh faktor kebutuhan dan psikologi.Dengan demikian persepsi seseorang tentang pendidikan berbeda satu dengan lainnya. Penelitian ini bertujuan menjelaskan persepsi orang tua terhadap proses bimbingan belajar anak di rumah.Jenis penelitian ini adalah penelitian kualitatif dengan menggunakan langkah-langkah reduksi data, penyajian data, penarikan kesimpulan dan verifikasi.Adapun hasil dari penelitian ini adalah orang tua yang memiliki pendidikan rendah kurang peduli terhadap bimbingan belajar siswa di rumah sehingga mengakibatkan banyak siswa pada kalangan orang tua berpendidikan rendah minat belajarnya kurang sampai menimbulkan putus sekolah.Siswa pada orang tua berpendidikan tinggi lebih beruntung, sebab bimbingan belajar saat di rumah bisa didapatkan oleh orang tua walaupun pada kalanya terkendala dengan kesibukan pekerjaan orang tua.
\end{abstract}

Kata Kunci: persepsi, bimbingan belajar, penelitian kualitatif

\begin{abstract}
Perception is always related to the symptoms and experience. The more experience and knowledge a person gains, the more and more perceptions he has. In addition to science and experience, perceptions are also influenced by factors of needs and psychology. Thus, one's perception of education differs from one another. This research aims to explain the perceptions of parents in the process of child counseling at home. It is a qualitative research using data reduction, data presentation, conclusion and verification. The results of this research are poorly educated parents just pay little attention to the student's learning guidance at home, resulting in many students showing little learning interest and dropping out of school. Students with highly educated parents are more lucky because the learning guidance can be obtained from their parents at home even though their parents's activities at times become constraints.
\end{abstract}

Keywords: perception, learning guidance, qualitative research

\section{PENDAHULUAN}

Persepsi merupakan salah satu proses pengolahan informasi yang ditangkap melalui indera penglihatan, pendengaran, perasaan, dan pengamatan yang diproyeksikan pada bagian tertentu di otak sehingga timbul untuk mengamati pada obyek tersebut. Kemudian ditafsirkan dalam buah pikiran dan mengasimilasikan suatu pengamatan berdasarkan pengalaman yang dimiliki [1]. Dengan demikian akan timbul tanggapan dan rangsangan baru. Tanggapan dan rangsangan tersebut dapat dipengaruhi oleh bahan atau pengalaman yang telah ada sehingga tanggapan dan rangsangan tersebut tidak diterima begitu saja, melainkan harus diamati dan digolongkan dalam sesuatu tertentu. Persepsi selalu berkaitan dengan gejala dan pengalaman yang dimiliki. Semakin banyak pengalaman dan ilmu pengetahuan maka akan semakin banyak dan kuat persepsinya, demikian juga sebaliknya.

Dengan adanya perbedaan persepsi antara satu orang dengan yang lainnya, meskipun dalam satu obyek, maka penulis tertarik untuk mengetahui serta menjelaskan bagaimana persepsi orang tua terhadap pendidikan anak dan bagaimana pengaruh 
pandangan tersebut terhadap proses bimbingan belajar anak di rumah. Kita tahu bahwa antara pendidikan anak dengan proses bimbingan belajar anak di rumah merupakan satu kesatuan yang integral. Dimana bimbingan belajar anak di rumah akan menunjang keberhasilan pendidikan anak. Seperti yang diungkapkan Ahmad Komaruzaman bahwa seorang anak selain mendapat pendidikan formal juga harus mendapatkan pendidikan informal yang diperolehnya di lingkungan dan keluarga [2].

Menurut hemat penulis, pendidikan pada hakekatnya adalah sebuah aktivitas yang penuh kesadaran dan tanggung jawab yang dilakukan oleh seorang dewasa terhadap anak sehingga timbul interaksi antara keduanya yang bertujuan mengarahkan anak berbuat sesuai dengan tujuan pendidikan. Dengan demikian dapat simpulkan pendidikan dapat berlangsung apabila terjadi : aktivitas sadar, orang dewasa sebagai pendidik, anak didik, interaksi timbal balik, dan tujuan yang ingin dicapai [3].

Mery Novianti berpendapat bahwa keberhasilan pendidikan ditentukan oleh faktor-faktor pendidikan itu sendiri, yaitu : anak didik, pendidik, alat-alat pendidikan, tujuan pendidikan dan melieu (lingkungan) [4]. Dengan demikian dapat dipahami bahwa pendidikan baru dapat berlangsung bila terdapat anak didik yang berfungsi sebagai obyek dan subyek didik, pendidik yaitu orang yang membawa anak didik pada tujuan, tujuan pendidikan yaitu apa yang menjadi sasaran atau tujuan pendidikan, alat-alat pendidikan yaitu sarana untuk mempermudah proses pendidikan dan melieu (lingkungan) adalah tempat proses pendidikan. Kelima hal tersebut di atas berhubungan sangat erat satu sama lain (integeral). Apabila tidak ada salah satunya maka proses pendidikan akan mengalami kepincangan atau mungkin kegagalan.

Pendidikan berdasarkan sifatnya dibagi menjadi : Pendidikan formal, informal dan non formal. Pendidikan formal adalah pendidikan yang berlangsung secara teratur, bertingkat dan mengikuti sifat-sifat tertentu secara ketat [5]. Pendidikan formal lazimnya diberikan di sekolah atau lembaga-lembaga lain yang bersifat formal.Sekolah memiliki peranan yang sangat penting dalam usaha menseoadewasakan anak dan menjadikannya sebagai anggota masyarakat yang berguna, juga bertanggung jawab atas anggota masyarakat yang dihasilkannya.

Pendidikan informal diperoleh seorang dari pengalaman sehari-hari dengan sadar atau tidak sadar sepanjang hayat pendidikan dapat berlangsung dalam keluarga dalam pengalaman sehari-hari maupun dalam pekerjaan, masyarakat, keluarga dan organisasi [6]. Sedangkan pendidikan non formal adalah pendidikan yang dilaksanakan secara tertentu dan sadar tetapi tidak mengikuti aturan yang ketat, diberikan pada kursus-kursus, pelatihan dan sebagainya [7].

Bimbingan belajar adalah jenis bimbingan yang memberikan bantuan kepada individu dalam memecahkan kesulitan-kesulitan yang berhubungan dengan masalah belajar [8]. Dengan demikian dapat dipahami bahwa bimbingan belajar adalah usaha membantu anak dalam menghadapi kesulitan belajar, apabila di sekolah dilakukan dan menjadi tugas dari BP, maka di rumah menjadi tugas orang tua. Agar pengertian lebih jelas dan mudah dipahami, penulis akan menguraikan tentang apa yang dimaksud bimbingan dan belajar secara terpisah. Bimbingan secara bahasa adalah terjemahan dari bahasa Inggris 'guidance'.W.S. Winkel 
menyatakan 'guidance' memiliki hubungan dengan guiding shawing away (menunjukan jalan), leading (memimpin), conducting (menuntun), giving instruction (memberikan petunjuk), regulation (mengatur), governing (mengatur), giving advice (memberikan nasihat). Sehingga dapat disimpulkan bimbingan menurut W.S. Winkel mengandung unsur : menunjukan jalan, memimpin, menuntun, memberi petunjuk, mengatur, mengarahkan dan memberi nasehat.

Bimbingan Belajar di Sekolah Menengah, menyatakan bimbingan adalah Suatu proses pemberian bantuan secara terus menerus dan sistematik dari pembimbing kepada peserta bimbing agar tercapai pemahaman diri, pengarahan diri, dan perwujudan diri dalam mencapai perkembangan yang optimal sehingga dapat menyesuaikan diri dengan lingkungan dan memperoleh kebahagian hidup [9]. Dari uraian di atas dapat disimpulkan bahwa bimbingan dilakukan dengan maksud agar peserta bimbing dapat menyesuaikan diri dengan lingkungannya dan memperoleh kebahagian hidup, agar bimbingan berhasil dengan baik maka harus dilakukan secara terus menerus.

Pengertian belajar menurut Robert $\mathrm{M}$ Gagne, dalam buku The Condition of Learning yang dikutip Abdul Rahman Abror "Learning is a change in human disposition or capacity, which persists over period of time and which is not simply ascribable to processes of growth" diartikan belajar merupakan sejenis perubahan yang diperlihatkan dalam perubahan tingkah laku, yang keadaannya berbeda dari sebelum individu berada dalam situasi belajar dan sesudah melakukan tindakan yang serupa itu [10].

Belajar merupakan proses perbuatan yang dilakukan dengan sengaja, yang kemudian menimbulkan perubahan yang keadaannya berbeda dari perubahan yang ditimbulkan oleh lainnya [11]. Definisi di atas dapat disimpulkan bahwa : belajar menimbulkan perubahan dalam arti tingkah laku kapasitas yang relatif tetap, perubahan itu pokoknya membedakan antara sebelum individu berada dalam situasi belajar dan sesudah melakukan belajar, kegiatan dilakukan lewat kegiatan atau usaha atau praktek yang disengaja atau diperkuat. Jadi kita dapat mengamati suatu perbuatan tetapi kita dapat mengamati belajar, artinya perbuatan yang menampakan pada perubahan. Dalam hubungan ini perubahan bisa dapat bersifat vertikal, dalam arti, bertambahnya ketelitian dalam melakukan sesuatu perbuatan atau bertambahnya informasi tentang apa yang dipelajari. Demikian juga dapat bersifat horisontal, dalam arti, hasil perubahan tersebut diintegrasikan dan diorganisasikan sebagai suatu bagian unit yang berfungsi memperluas, menambah dan memperkaya pengalaman.

Untuk mendapatkan hasil yang maksimal, maka diperlukan langkah-langkah dan teknik bimbingan belajar anak di rumah. Pertama kita membahas langkah-langkah bimbingan belajar anak. Secara formal, sebenarnya bimbingan belajar anak di rumah tidak memerlukan langkah-langkah seperti yang sering digunakan oleh seorang konselor dalam memberikan bantuan kepada anak murid atau kliennya.Sebab anak lahir dalam pemeliharaan orang tua dan dibesarkan dalam keluarganya. Orang tua tanpa ada yang memerintah langsung memikul tugas sebagai pendidik baik bersifat sebagai pemelihara, pengasuh, pembina, sebagai guru dan sudah tentu sebagai pembimbing. Dengan demikian, maka sudah pasti orang tua mengetahui kesulitan-kesulitan yang dihadapi anak dalam belajar. Namun ada baiknya penulis menguraikan juga langkah-langkah yang biasa ditempuh dalam melakukan suatu 
bimbingan, termasuk bimbingan belajar menurut pendapat ahli.

Tulisan ini bertujuan untuk mengetahui persepsi orang tua terhadap proses bimbingan belajar anak di rumah sehingga orang tua disarankan memiliki bekal pendidikan yang cukup. Dan dianjurkan untuk meluangkan waktu guna memberi bimbingan kepada putra-putrinya.

\section{METODE}

Pendekatan yang dipakai dalam penenilitian ini adalah pendekatan kualitatif, dengan maksud bahwa pendekatan kualitatif adalah suatu proses penelitian dan pemahaman yang berdasarkan pada metodologi yang menyelidiki suatu fenomena social dan masalah manusia. Dalam pendekatan ini peneliti mencoba membuat suatu gambaran dari kata-kata, laporan terinci dari pandangan responden, dan melaksanakan studi yang berlangsung pada situasi secara alami. Peneliti menggunakan pendekatan kualitatif disebabkan karena penelitian kualitatif merupakan penelitian yang melibatkan diri peneliti secara langsung dalam melakukan penelitian baik melakukan pengamatan, wawancara, dan lain sebagianya agar peneliti dapat memahami permasalahan yang sedang diamati atau sedang diteliti.

Peneliti mengambil mengambil lokasi di Desa Margamulya Kecamatan Mauk Kabupaten Tangerang dengan pertimbangan bahwa peneliti bertempat tinggal di Desa Margamulya Kecamatan Mauk Kabupaten Tangerang. Pertimbangan lain lokasi yang diambil di daerah ini disebabkan karena adanya permasalahan yang terkait dengan kesadaran untuk bersekolah yang masih rendah, ini terlihat dari banyaknya siswa yang hanya tamatan Sekolah Dasar, dan hanya sebagian yang melanjutkan ke jenjang SLTP serta SLTA.
Sumber data penelitian ini adalah orang tua yang memiliki anak usia sekolah dengan kondisi ekonomi dan jenis pekerjaan yang berbeda. Pengambilan data dalam penelitian ini menggunakan cara purposive sampling, yaitu peneliti menentukan terlebih dahulu criteria-kriteria sampel yang akan diambil. Kriterian sampel yang diambil pada penelitian ini adalah orang tua yang memiliki tingkat pendidikan Sekolah Dasar dan orang tua yang memiliki tingkat pendidikan Sekolah Menengah Pertama, orang tua yang memiliki tingkat pendidikan Sekolah Menengah Atas, dan orang tua yang memiliki tingkat pendidikan Diploma/Sarjana, sebagai sumber data dalam hal informan, peneliti menentukan satu atau dua informan yang memiliki tingkat pendidikan Sekolah Dasar, yang memiliki tingkat pendidikan Sekolah Menengah Pertama, yang memiliki tingkat pendidikan Sekolah Menengah Atas, dan orang tua yang memiliki tingkat pendidikan Diploma/Sarjana

Teknik yang dipakai dalam pengambilan data adalah menggunakann observasi, wawancara, dan dokumentasi, dengan teknik ini diharapkan peneliti memperoleh informasi yang berkaitan dengan data penelitian yang diharapkan oleh peneiliti. Teknik analisis data yang digunakan dalam penelitian kualitatif dilakukan dengan langkah-langkah antara lain: (1) Reduksi data, (2) Penyajian data, (3) Penarikan kesimpulan dan verifikasi. Adapun untuk memperoleh keabsahan data, peneliti menggunakan teknik triangulasi, dengan maksud sebagai pengecekan data dari berbagai sumber dengan cara dan berbagai waktu sehingga memperoleh data yang bisa dipertanggungjawabkan keabsahannya.

\section{HASIL DAN PEMBAHASAN}

Informan atau sumber data dalam penelitian ini adalah orang tua yang 
memiliki anak usia sekolah dan memiliki tingkat pendidikan tertentu,dalam hal ini adalah orang tua yang memiliki tingkat pendidikan Sekolah Dasar,orang tua yang memiliki tingkat pendidikan Sekolah Menengah Pertama, orang tua yang memiliki tingkat pendidikan Sekolah Menengah Atas, dan orang tua yang memiliki tingkat pendidikan Diploma/Sarjana. Adapun data orang tua yang dijadikan informan dapat terlihat pada tabel berikut:

Tabel 1. Identitas orang tua yang menjadi informan

\begin{tabular}{clrl}
\hline No & Nama & Umur & \multicolumn{1}{c}{ Pendidikan } \\
\hline 1 & Suherman & 40 tahun & SD \\
2 & Yanto & 45 tahun & SD \\
3 & Arpan & 49 tahun & SMP \\
4 & Widodo & 40 tahun & SMP \\
5 & Ocan & 50 tahun & SMA \\
6 & Joko & 47 tahun & SMA \\
7 & Dedi & 45 tahun & Diploma/sarjana \\
8 & Supardi & 48 tahun & Diploma/sarjana \\
\hline
\end{tabular}

Persepsi masyarakat dengan tingkat pendidikan rendah tentu akan berbeda dengan masyarakat dengan tingkat pendidikannya lebih tinggi, tingkat pendidikan pada dasarnya akan mempengaruhi pola piker terutama dalam mempertahikan kebutuhan pendidikan bagi anak-anaknya.

Berdasarkan hasil wawancara terhadap orang tua yang memiliki tingkat pendidikan baik Sekolah Dasar, Sekolah Menengah Pertama, Sekolah Menengah Atas ataupun Diploma/Sarjana, mereka menganggap bahwa pendidikan sangat penting bagi anak-anaknya, nanum terdapat perbedaan pandangan terhadap bimbingan belajar di rumah. Untuk orang tua yang tingkat pendidikannya Sekolah Dasar dan Sekolah Menengah pertama memiliki persepsi bahwa mereka tidak terlalu peduli terhadap belajar anaknya ketika ada di rumah, mereka beralasan ketidak mampuan untuk membimbing dan mengarahkan anaknya dalam pelajaran sekolah, yang lebih mengkewatirkan bahwa banyak perubahan sikap perilaku anak yang kurang nurut terhadap orang tua sehingga para orang tua dari kalangan berpendidikan Sekolah Dasar dan Sekolah Menengah Pertama hanya mengandalkan bimbingan para guru di sekolah.Pada orang tua yang memiliki tingkat pendidikan Sekolah Menengah Atas ataupun Sarjana, mereka menyampaikan bahwa bimbingan belajar di rumah sangat penting, tetapi terkendala waktu yang kurang cukup dikarenakan kesibukan pekerjaan yang mereka lakukan.

Latar belakang orang tua yang rendah merupakan suatu hal yang mempengaruhi pola bimbingan belajar siswa dirumah, perhatian yang kurang mengakibatkan siswa mendapatkan kejenuhan sampai terjadinya putus sekolah.

\section{SIMPULAN DAN SARAN}

Berdasarkan hasil observasi dan wawancara yang telah dipaparkan pada pembahasan dapat disimpulkan bahwa persepsi orang tua terhadap bimbingan belajar di rumah sangat membantu perkembangan siswa dalam menempuh pendidikan di sekolah, namun pada kenyataannya orang tua yang memiliki pendidikan rendah kurang peduli terhadap bimbingan belajar siswa di rumah sehingga mengakibatkan banyak siswa pada kalangan orang tua berpendidikan rendah minat belajarnya kurang sampai menimbulkan putus sekolah. Siswa pada orang tua berpendidikan tinggi lebih beruntung, sebab bimbingan belajar saat di rumah bisa didapatkan oleh orang tua walaupun pada kalanya terkendala dengan kesibukan pekerjaan orang tua.

Beradasarkan pada simpulan yang telah diambil oleh peneliti, maka peneliti menyarankan agar: (1) Pemerintah melalui aparat Desa atau Kecamatan, diharapkan lebih gencar atas pentingnya pendidikan 
bagi anak usia sekolah dengan member perhatian lebih pada anak. (2) Hendaknya orang tua agar memberikan perhatian lebih terhadap pendidikan anak, member dorongan dan bimbingan belajar pada anak, meningkatkan control dan pengawasan sehingga lebih rajin untuk melakukan belajar baik di rumah maupun di sekolah.

\section{UCAPAN TERIMA KASIH}

Kepada berbagai pihak yang telah membantu penelitian ini, peneliti mengucapkan banyak terimakasih kepada: (1) Kepala Desa Margamulya beserta staf yang telah member masukan kepada peneliti dalam penentuan sampel. (2) Para responden yang telah berkenan meluangkan waktu guna memberikan keterangan proses wawancara. (3) Kepada semua pihak yang tidak bisa disebutkan satu persatu yang telah membantu baik secara moril maupun materiil.

\section{DAFTAR PUSTAKA}

[1] Muchtar Yunus, Persepsi Orang tua terhadap pendidikan dan kecenderungannya dalam pemilihan jenis pendidikan anaknya ( Suatu studi dikelurahan jepara, surabaya utara). Universitas Erlangga, Surabaya. 2014

[2] Ahmad, Komaruzaman. Pengaruh Persepsi Siswa Tentang Metode Mengjar Gur, Fasilitas Belajar dan Motivasi Belajar Terhadap Prestasi Belajar Siswa Kompetensi Keahlian Teknik Audio Video di SMK N3 Yogyakarta. S1 thesis, UNY. 2015

[3] Ella, A. The impact of motivation on students academic achievement and learning outcomes in mathematics among secondary school students in Nigeria. Eurasia Journal of Mathematics, Science \& Technology Education, 3 (2), 149-156. 2017.

[4] Mery Novinyanti. Pengaruh Motivasi dan Keterampilan berkomunikasi terhadap prestasi belajar Mahasiswa pada Tutorial Online berbasis Pendekatan Kotekstual Pada Matakuliah Statistik Pendidikan. Jurnal Pendidikan,[S.1.], v.12, n. 2, p. 80-88, aug. 2017.

[5] Noviyanti, M. laporan penelitian kesiapan tutor universitas terbuka dalam memanfaatkan fasilitas tutorial online. Jakarta: Universitas Terbuka. 2016.

[6] G. Gresham. "A Study Exploring Exceptional Education Pre-service Teachers" Mathematics Anxiety". IUMPST: The Journal, vol. 4, 2010.

[7] Suwarto. Strategi Pembelajaran Operasi Bilangan dengan Benda Konkrit. UNION: Jurnal Pendidikan Matematik, Vol 5 No 3, November 2017

[8] John Gottman. Kiat-kiat Membesarkan Anak yang Memiliki Kecerdasan Emosional. Jakarta PT Gramedia Pustaka Utama, 2001.

[9] Hendra Surya. Strategi Jitu Mencapai Kesuksesan Belajar. Jakarta: PT. Gramedia, 2011.

[10] Sia Tjundjing. Hubungan antara IQ, EQ, dan QA dengan Prestasi Study Pada Siswa SMU. Journal Anima, Vol. 17, No. 1. UPI Surabaya, 2011.

[11]Zubaidah, S., Mahanal, S. \& Mulyati, Y. Penerapan Pola Pembelajaran Pemberdayaan Berpikir Melalui Pertanyaan (PBMP) Dengan Metode TPS pada Mata Pelajaran IPA Untuk Meningkatkan Keaktivan dan Hasil Belajar Siswa Kelas IV Madrasah Ibtidaiyah Jenderal Sudirman (MIJS) Malang. Makalah Disajikan Dalam Seminar nasional Biologi dan Pembelajarannya, Jurusan Biologi FMIPA Universitas Negeri Malang, Malang 3 Desember. 2015.

[12] Moleong, J. L. Metodologi Penelitian Kualitatif. Bandung: CV.Remaja Rosdakarya. 2010. 